\title{
Promotion and Inhibition of Soil Aggregate Stabilization by Micro-organisms
}

\author{
By J. M. LYNCH \\ Agricultural Research Council Letcombe Laboratory, Wantage, Oxon OX12 9JT, U.K.
}

(Received 23 February 1981)

\begin{abstract}
Microbial cells in suspension were added to two soils. After drying, the degree of aggregation and stability of the aggregates to water was estimated by adding water, shaking and measuring turbidimetrically the particles remaining in suspension. In a silt loam (Hamble series), Azotobacter chroococcum, Lipomyces starkeyi and Pseudomonas sp. all promoted the stabilization of aggregates, this being related to the number of cells added, but Mucor hiemalis inhibited the process. In a clay soil (Denchworth series), Mucor hiemalis and Pseudomonas sp. both promoted stabilization. The stabilization of the silt loam by Lipomyces starkeyi was also produced by the polysaccharide extracted from the cell.
\end{abstract}

\section{INTRODUCTION}

Aggregation in soil is the coalescence of particles to form aggregates, and stability is a measure of the resistance of the aggregates to stress. Waksman \& Martin (1939) were the first to observe that micro-organisms, particularly fungi, could bind soils into stable masses. Similar conclusions were reached by McCalla (1946), Swaby (1949), Harris et al. (1964), Aspiras et al. (1971) and Gasperi-Mago \& Troeh (1979).

From their relative sizes, bacteria seem likely to provide the cementing action between particles and fungi the binding action around them. Microbial polysaccharides are at least partially involved in this action (for reviews, see Hepper, 1975; Lynch, 1976). Microorganisms have the potential to bind soil particles by both adhesion of extracellular polymers and enzymes and by charge interactions (Burns, 1980; Fletcher et al., 1980; Stotzky, 1980), but no investigation has clearly distinguished these effects.

An objection to some of the earlier studies is that micro-organisms were added to soils with large quantities of unnatural substrates, such as free glucose, and aggregate stability was measured after a period of incubation of a few days or weeks. The size of the increased biomass generated by incubation was unknown. The aim of the present experiments was to assess the interaction between the mass of microbial cells and soil particles. I have therefore added known cell biomasses to soils and avoided incubation, so that any increase in stability is only associated with the added cell mass.

Several methods have been used to estimate the stability of soil aggregates to water after treatment with micro-organisms; these include wet-sieving (Skinner, 1979), disintegration by dropping water (Griffiths \& Jones, 1965), and shaking in water to release particles into suspension which are measured by turbidimetry (Gilmour et al., 1948). It is not clear which is the most meaningful technique (Emerson et al., 1978) and the relationship between laboratory determinations and soil stability in the field is uncertain. However, Williams et al. (1966) have argued in favour of the turbidimetric procedure for comparing small soil samples. Therefore this procedure has been used here to investigate the stability of two soils following the addition of known cell biomasses of micro-organisms (two bacteria, a yeast and a fungus) which are not only widespread but are frequently dominant in the soil or rhizosphere. The 
technique used measures a combination of aggregation and stability. The structural stabilities of the two soils studied differed greatly, the silt loam (Jarvis, 1968) having a much weaker structure than the clay (Jarvis, 1973). The aggregates of the former were more prone to slaking and destruction by water.

\section{METHODS}

Soils. A clay soil (classification: UK, Stagnogley; USDA, Typic Haplaquept; FAO/UNESCO, Eutric Gleysol) and a silt loam (classification: UK, Argillic Brown Earth; USDA, Typic Haplundalf; FAO/UNESCO, Orthic Luvisol) were used. The soils were air-dried and sieved to pass a $2 \mathrm{~mm}$ mesh. Their characteristics are summarized in Table 1. The oxidizable carbon content (Walkley \& Black, 1934) was estimated on a Technicon Auto Analyser by measuring the light absorption of the green colour produced by the reduction of potassium dichromate during the oxidation process; a sucrose solution was used for standardization. The natural biomass in the soil at the time of sampling (before air drying) was estimated from the results of Lynch \& Panting $(1980 \mathrm{~b})$. The $\mathrm{pH}$ was measured in a $1: 2.5$ suspension in water. The cation exchange capacity was determined by exchanging ammonium ions and extracting them with potassium chloride solution (Anon, 1973). The particle size distribution was found by dispersing peroxidized samples with sodium hexametaphosphate (Avery \& Bascombe, 1974). The Denchworth series soil had a greater clay content, of mixed composition (interstratified mica-montmorillonite/kaolinite/mica in the ratio $2: 1: 1$ ), and a larger cation exchange capacity than the Hamble series silt loam.

Micro-organisms. All micro-organisms were grown at $25^{\circ} \mathrm{C}$ for $7 \mathrm{~d}$ unless specified otherwise. A Pseudomonas sp. was isolated as a dominant colonist of the rhizosphere of maize and cultured on nutrient broth (Bennett \& Lynch, 1981). Azotobacter chroococcum, which has been used as a seed inoculant to stimulate plant growth, was cultured on a defined medium with added nitrogen as described by Harper \& Lynch (1979). Lipomyces starkeyi, a common soil yeast, was grown for $14 \mathrm{~d}$ on a medium containing glucose $\left(50 \mathrm{~g} \mathrm{I}^{-1}\right)$ and peptone $\left(10 \mathrm{~g} \mathrm{I}^{-1}\right)$. The polysaccharide of this yeast was extracted as described by Jones \& Griffiths (1967). Mucor hiemalis was grown on a defined medium as described by Lynch \& Harper (1974).

The cells were harvested by centrifugation, resuspended in fresh deionized water and re-centrifuged. This procedure was repeated three times. The cells or polysaccharide were then suspended in deionized water at a known concentration with respect to dry weight. The fungal mycelium was lightly homogenized to produce a uniform suspension.

Addition of micro-organisms to soil. Soil $(2 \mathrm{~g})$ was placed in a boiling tube (capacity $100 \mathrm{ml}$ ). A portion of the microbial suspension was added and the total liquid volume was made up to $10 \mathrm{ml}$ with deionized water. In controls, no micro-organisms were added. The resulting slurry was shaken vigorously and left to dry for $18 \mathrm{~h}$ at $60^{\circ} \mathrm{C}$ to produce a solid mass which adhered to the tube. This temperature was considered the minimum necessary to prevent microbial growth and allow fairly rapid drying.

Determination of aggregate stability. Deionized water $(60 \mathrm{ml})$ was added to the soil. The tube was stoppered and inverted end-over-end 20 times at a constant rate over a period of $45 \mathrm{~s}$, which liberated the solid mass into suspension. The tube contents were then transferred to a fresh tube, and this was placed in a turbidimeter similar to that described by Davidson \& Evans (1960). The reading on the digital voltmeter output was determined after a further $60 \mathrm{~s}$, that being the time when rapid changes in the readings ceased.

The contribution of micro-organisms themselves to the turbidity was assessed. Portions of the microbial suspensions were added to tubes without soil and dried. Deionized water $(60 \mathrm{ml})$ was then added to each tube and

Table 1. Characteristics of soils used

\begin{tabular}{|c|c|c|c|c|c|c|c|c|}
\hline \multirow[b]{2}{*}{ Type } & \multirow[b]{2}{*}{$\begin{array}{l}\text { Soil series } \\
\text { (location) }\end{array}$} & \multirow[b]{2}{*}{$\begin{array}{c}\text { Organic } \\
\text { matter } \\
(\%, w / w)\end{array}$} & \multirow{2}{*}{$\begin{array}{l}\text { Approximate } \\
\text { microbial } \\
\text { biomass } \\
\mid \mathrm{mg}(\mathrm{g} \mathrm{dry} \\
\text { soil })^{-1} \mid\end{array}$} & & \multicolumn{3}{|c|}{ Particle size distribution (\%) } & \multirow{2}{*}{$\begin{array}{c}\text { Cation } \\
\text { exchange } \\
\text { capacity } \\
(\mathrm{m} \text {-equiv } \\
(100 \mathrm{~g})^{-1}\end{array}$} \\
\hline & & & & $\mathrm{pH}$ & $\begin{array}{l}\text { Clay } \\
(<2 \\
\mu \mathrm{m})\end{array}$ & $\begin{array}{c}\text { Silt } \\
(2-63 \\
\mu \mathrm{m})\end{array}$ & $\begin{array}{c}\text { Sand } \\
(>63 \\
\mu \mathrm{m})\end{array}$ & \\
\hline $\begin{array}{l}\text { Silt } \\
\text { loam }\end{array}$ & $\begin{array}{l}\text { Hamble } \\
\text { (Englefield, } \\
\text { Berks) }\end{array}$ & $1 \cdot 2$ & 0.24 & 6.5 & 16 & 64 & 20 & 9.0 \\
\hline Clay & $\begin{array}{l}\text { Denchworth } \\
\text { (Compton } \\
\text { Beauchamp, } \\
\text { Oxon) }\end{array}$ & 4.7 & 1.50 & $6 \cdot 2$ & 49 & 47 & 4 & $30 \cdot 0$ \\
\hline
\end{tabular}


the turbidity was measured. The turbidities measured never exceeded the equivalent of $0.4 \%(w / v)$ suspended soil so this effect could be ignored.

A calibration curve of turbidity against percentage suspended soil (i.e. the proportion of the soil in suspension after standing for $1 \mathrm{~min}$ ) was constructed. Soil was added to deionized water in a tube, inverted 20 times during 45 $\mathrm{s}$ and left to settle for $1 \mathrm{~min}$. Samples were pipetted into fresh tubes, the volumes were made up to $60 \mathrm{ml}$ and the turbidities were determined. The suspension was then filtered through a weighed filter paper, dried and reweighed. A calibration curve of turbidity against the percentage of suspended soil when $2 \mathrm{~g}$ soil was shaken in water was produced. The treatments resulting in the least amount of suspended soil were taken to have the greatest aggregate stability.

\section{RESULTS}

The calibration curve for weight of suspended soil against turbidity was the same for both soils. However, because the soils have such different compositions, use of the turbidity method to compare the structural stabilities of the two soils would probably be misleading.

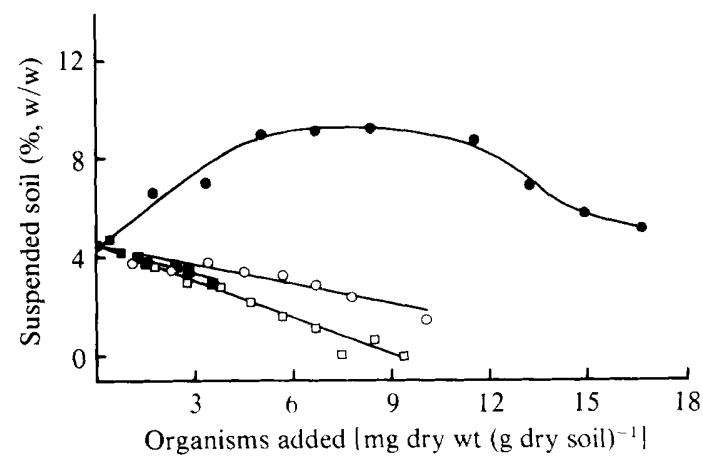

Fig. 1. Effect of micro-organisms on stability of a silt loam (Hamble series): Mucor hiemalis; $\mathrm{O}$, Azotobacter chroococcum; $\mathbf{\square}$, Lipomyces starkeyi; $\square$, Pseudomonas $\mathrm{sp}$.

Table 2. Effect of Pseudomonas sp. and Mucor hiemalis on soil aggregation

$\begin{array}{lccc}\text { Micro-organism } & \begin{array}{l}\text { Biomass added } \\ \left.\text { [mg dry wt (g dry soil) }{ }^{-1}\right]\end{array} & \overbrace{\text { Hamble series* }}^{\text {Suspended soil }(\%, \mathrm{w} / \mathrm{w})} & \text { Denchworth series } \\ \text { Pseudomonas sp. } & 6 \cdot 5 & 2 \cdot 2 & 2 \cdot 2 \\ \text { Mucor hiemalis } & 5.5 & 9 \cdot 0 & 2 \cdot 5 \\ \text { None (control) } & - & 4 \cdot 5 & 5 \cdot 5 \\ \text { Least significant difference }(P=0.05) & & 1.0\end{array}$

* By interpolation from Fig. 1.

Table 3. Comparison of the effect of Lipomyces starkeyi and its polysaccharide on the aggregation of a silt loam (Hamble series)

The same weight of polysaccharide was added in each treatment $\left.\{1 \mathrm{mg} \text { dry wt (g dry soil })^{-1}\right\}$ on the assumption that the polysaccharide is $50 \%$ of the cell dry weight (Jones \& Griffiths, 1967).

$\begin{array}{lc}\text { Form of polysaccharide added } & (\%, w / w) \\ \text { Cells } & 3.6 \\ \text { Purified extract } & 2.9 \\ \text { None (control) } & 4.7 \\ \text { Least significant difference }(P=0.05) & 1.0\end{array}$


When the bacteria and the yeast were added to the silt loam, aggregation was increased in proportion to the amount of organism added (Fig. 1). Azotobacter chroococcum seemed slightly less effective than Lipomyces starkeyi and Pseudomonas sp. The fungus Mucor hiemalis visibly promoted the aggregation of the soil after drying but the stability determined turbidimetrically was usually less than in soil without added organisms, although when very large amounts of organism were added the stability was similar to that of the unamended soil. This adverse effect of the fungus was not found in the clay soil; both visibly and turbidimetrically it had the same stabilizing effect as Pseudomonas sp. (Table 2).

A comparison of the effect of $L$. starkeyi and its associated polysaccharide showed that the purified polysaccharide was slightly more effective than the cell-bound material in promoting stabilization, but this difference was not significant (Table 3).

\section{DISCUSSION}

The finding that a common and widespread saprophytic soil fungus has the ability to produce stable aggregates of the clay under the test conditions is consistent with earlier investigations referred to in the Introduction. However, the inhibition of aggregation in the silt loam was unexpected. The fungus is unlikely to have destroyed aggregating agents as suggested by Aspiras et al. (1971), because there was no growth. The result is, however, similar to that of Gilmour et al. (1948): in soils unamended by organic additions, aggregation was promoted by growing fungi in those with 45 and $21 \%(w / w)$ clay, but not in one with only $11 \%$.

Mycelium was homogenized and all cells were killed by heat, so that in this study microbial products rather than the cells per se were the principal agents in promoting or inhibiting stability. This would be consistent with the report of Harris et al. (1964) who suggested that microbial products and not numbers determine aggregate stabilization. The observations on the yeast and its polysaccharide are also consistent with this view.

It is useful to relate the microbial mass added to the soils in the laboratory system used here to that which can be present under field conditions. Modification of agricultural practices can alter the size of the soil microbial biomass (Lynch \& Panting, 1980a,b), but the increase is seldom more than a factor of two. The present observations show that this could bring about only a small increase in aggregate stability. However, there is a much greater increase in the biomass immediately around the roots (the rhizosphere) and particularly on the roots (the rhizoplane). The rhizosphere biomass is difficult to estimate but the number of bacterial propagules in the rhizosphere soil has long been known to be greater than that in the bulk soil by a factor of about ten (Wallace \& Lochhead, 1949). Thus, the greatest potential for an increase in aggregate stability is around roots and indeed the growth of roots in soil is well known to promote aggregate stabilization (Allison, 1968; Harris et al., 1966; Reid \& Goss, 1980), although the contributions of the roots per se and micro-organisms have never been clearly distinguished. There is probably a dynamic balance between stimulation and inhibition of soil aggregation by micro-organisms but more work is clearly necessary, particularly on the effect of growing cells.

I thank Dr D. Jones for providing me with the Lipomyces starkeyi culture and its extracted polysaccharide, Miss Lynda Panting for technical help and Professor C. M. Gilmour, Mr J. T. Douglas and Mr S. H. T. Harper for helpful discussion.

\section{REFERENCES}

Allison, F. E. (1968). Soil aggregation - some facts and fallacies as seen by a microbiologist. Soil Science 106, 136-143.
ANON (1973). The Analysis of Agricultural Materials. Ministry of Agriculture, Fisheries and Food Technical Bulletin 27. London: HMSO. 
Aspiras, R. B., Allen, O. N., Harris, R. F. \& Chesters, G. (1971). Aggregate stabilization by filamentous micro-organisms. Soil Science 112 , $282-284$.

Avery, B. W. \& Bascombe, C. L. (1974). Soil Survey Laboratory Methods. Harpenden: Soil Survey of England and Wales.

BenNetT, R. A. \& LYNCH, J. M. (1981). Bacterial growth and development in the rhizosphere of gnotobiotic cereal plants. Journal of General Microbiology 125, 95-102.

BurNs, R. G. (1980). Microbial adhesion to soil surfaces: consequences for growth and enzyme activities. In Microbial Adhesion to Surfaces, pp. 249-262. Edited by R. C. W. Berkeley, J. M. Lynch, J. Melling, P. R. Rutter \& B. Vincent. Chichester: Ellis Horwood.

Davidson, J. M. \& Evans, D. D. (1960). Turbidimeter technique for measuring the stability of soil aggregates in a water-glycerol mixture. Soil Science Society of America Proceedings 24, 75-79.

EMERSoN, W. W., Bond, R. D. \& DEXTER, A. R. (editors) (1978). Modification of Soil Structure. Chichester: John Wiley,

Fletcher, M., Latham, M. J., Lynch, J. M. \& RutTer, P. R. (1980). The characteristics of interfaces and their role in microbial attachment. In Microbial Adhesion to Surfaces, pp. 67-78. Edited by R. C. W. Berkeley, J. M. Lynch, J. Melling, P. R. Rutter \& B. Vincent. Chichester: Ellis Horwood.

Gasperi-Mago, R. R. \& Troeh, F. R. (1979). Microbial effects on soil erodibility. Soil Science Society of America Journal 43, 765-768.

Gilmour, C. M., Allen, O. N. \& Truog, E. (1948). Soil aggregation as influenced by the growth of mold species, kind of soil, and organic matter. Soil Science Society of America Proceedings 13, 292296.

Griffiths, E. \& Jones, D. (1965). Microbiological aspects of soil structure. I. Relationships between organic amendments, microbial colonization and changes in aggregate stability. Plant and Soil 23. 17-33.

HARPER, S. H. T. \& LYNCH, J. M. (1979). Effects of Azotobacter chroococcum on barley seed germination and seedling development. Journal of General Microbiology 112, 45-51.

Harris, R. F., Chesters, G., Allen, O. N. \& Attoe, O. J. (1964). Mechanisms involved in soil aggregate stabilization by fungi and bacteria. Soil Science Society of America Proceedings 28, 529-532.

Harris, R. F., Chesters, G. \& Allen, O. N. (1966). Dynamics of soil aggregation. Advances in Agronomy 18, 107-169.

Hepper, C. M. (1975). Extracellular polysaccharides of soil bacteria. In Soil Microbiology. A Critical Review, pp. 93-110. Edited by N. Walker. London: Butterworths.
Jarvis, M. G. (1973). Soils of the Wantage and Abingdon District. Harpenden: The Soil Survey.

JARvIS, R, A. (1968). Soils of the Reading District. Harpenden: The Soil Survey.

JoNES, D. \& GRIFfiThS, E. (1967). Microbiological aspects of soil structure. II. Soil aggregation by the extracellular polysaccharide of Lipomyces starkeyi. Plant and Soil 27, 187-200.

LYNCH, J. M. (1976). Products of soil micro-organisms in relation to plant growth. CRC Critical Reviews in Microbiology 5, 67-107.

LYNCH, J. M. \& HARPER, S. H. T. (1974). Formation of ethylene by a soil fungus. Journal of General Microbiology 80, 187-195.

LYNCH, J. M. \& PAnting, L. M. (1980a). Cultivation and the soil biomass. Soil Biology and Biochemistry 12, 29-33.

LynCh, J. M. \& Panting, L. M. (1980 b). Variations in the size of the soil biomass. Soil Biology and Biochemistry 12, 547-550.

McCalla, T. M. (1946). Influence of some microbial groups on stabilizing soil structure against falling water drops. Soil Science Society of America Proceedings 11, 260-263.

REID, J. B. \& Goss, M. J. (1980). Changes in the aggregate stability of a sandy loam effected by growing roots of perennial ryegrass (Lolium perenne). Journal of the Science of Food and Agriculture 31, 325-328.

Skinner, F. A. (1979). Rothamsted studies of soil structure VII. The effects of incubation on soil aggregate stability. Journal of Soil Science 30, 473-481.

Stotzky, G. (1980). Surface interactions between clay minerals and microbes, viruses and soluble organics, and the probable importance of these interactions to the ecology of microbes in soil. In Microbial Adhesion to Surfaces, pp. 231-247. Edited by R. C. W. Berkeley, J. M. Lynch, J. Melling, P. R. Rutter \& B. Vincent. Chichester: Ellis Horwood.

SWABY, R. J. (1949). The relationship between microorganisms and soil aggregation. Journal of General Microbiology 3, 236-254.

Waksman, S. A. \& Martin, J. P. (1939). The role of micro-organisms in the conservation of the soil. Science 90, 304-305.

WALKLEY, A. \& BlaCK, I. A. (1934). An examination of the Degtjareff method for determining soil organic matter, and a proposed modification of the chromic acid titration method. Soil Science 37, 29-38.

Wallace, R. H. \& LochHead, A. G. (1949). Qualitative studies of soil microorganisms. VII. Influence of various crop plants on the nutritional groups of soil bacteria. Soil Science 67, 63-69.

Williams, B. S., Greenland, D. J., Lindstrom, S. R. \& QuiRK, J. P. (1966). Techniques for the determination of soil aggregates. Soil Science 101, 157-163. 